\title{
PENGEMBANGAN PRODUK SPIDER FITTING BERDASARKAN ANALISA KEBUTUHAN KONSUMEN DENGAN MENGGUNAKAN METODE QUALITY FUNCTION DEPLOYMENT (QFD)
}

\author{
Ahmad, Agung Saryatmo, dan Hansel Christian \\ Program Studi Teknik Industri, Universitas Tarumanagara \\ e-mail: Hansel_christ12@yahoo.com
}

\begin{abstract}
ABSTRAK
Penelitian ini dilakukan untuk mengetahui kebutuhan konsumen pada produk Spider Fitting, sehingga perusahaan dapat memperbaiki dan mengembangkan kualitas produk mereka. Dalam mengidentifikasi keinginan konsumen didapatkan 7 voice of customer yang menjadi kebutuhan dan keinginan konsumen. Metode yang digunakan dalam penelitian ini adalah Quality Function Deployment (QFD). Penelitian ini mendapatkan hasil bahwa atribut perbaikan kualitas yang menjadi prioritas adalah kemudahan pengaturan sudut kaca, finishing permukaan, kemudahan dalam pemasangan dan kekuatan konstruksi. Technical response yang menjadi prioritas berdasarkan HOQ dengan nilai absolute importance 112,41 (26,15\%) yaitu spider fitting yang fleksibel dalam pengaturan sudut, prioritas ke 2 dengan nilai absolute importance 91,71 (21,34\%) yaitu finishing mirror, prioritas ke 3 dengan nilai absolute importance 68,79 (16\%) yaitu membuat kepala baut segi enam pada bagian baut penjepit kaca dan prioritas ke 4 dengan nilai absolute importance 65,48 (15,23\%) yaitu menggunakan plat dengan ketebalan 3mm-6mm. Dari 3 konsep usulan yang di buat maka dipilih konsep ke 3 yang dianggap lebih baik berdasarkan empat kreteria prioritas.
\end{abstract}

Kata kunci: Spider Fitting, QFD, API, HOQ

\begin{abstract}
This study was conducted to determine the needs of consumers on product spider fittings, so companies can improve and develop the quality of their products. In identifying consumer desires there's 7 voice of customer needs and consumers desires consumers. The method used in this research is Quality Function Deployment (QFD). From this study get the result that the atribute of quality improvement that become the priorities is the ease of setting the angle of the glass, surface finishing, ease of installation and construction strength. The first priority of technical response based on HOQ with absolute importance value is 112,41 (26,15\%) it means the setting of angle spider fitting must be flexible, the second priority with absolute importance value $91.71(21,34 \%)$ is mirror finishing, the third priority with absolute importance value $68,79(16 \%)$ is makes hexagon head bolts on the clamp bolt glass and the last priority with absolute importance value 65,48 (15,23\%) is using a metal sheet with a thickness of $3 \mathrm{~mm}$ $6 \mathrm{~mm}$, from 3 concept proposal created then the third concept is choosen because of considered better based on four criteria priorities.
\end{abstract}

Keywords: Spider Fitting, QFD, API, HOQ.

\section{PENDAHULUAN}

Suatu perusahaan harus memberikan apa yang di inginkan oleh konsumen, sehingga konsumen merasa puas akan produk yang telah di beli. Konsumen akan cenderung memilih produk yang memiliki kualitas tinggi, oleh karena itu industri yang bergerak dibidang manufaktur material stainless steel harus mengetahui, memahami, dan memenuhi keinginan para konsumen agar tidak kehilangan para pelangganya.

Melihat pentingnya kebutuhan konsumen dalam suatu industri manufaktur, maka saya sebagai peneliti tertarik untuk membahas topik Pengembangan Produk Spider Fitting Berdasarkan Analisa Kebutuhan Konsumen Dengan Menggunakan Metode Quality Function Deployment (QFD) untuk mengetahui prioritas yang harus diperhatikan oleh perusahaan demi upaya peningkatan kepuasan konsumen pada pelayanan yang diberikan oleh perusahaan manufaktur. 


\section{Definisi Kebutuhan Konsumen}

Customer needs adalah sesuatu yang dicari atau diharapkan oleh seseorang pelanggan dapat terpenuhi dengan mengkonsumsi suatu barang atau jasa tertentu. Perusahaan haruslah berupaya untuk dapat mengetahui apa yang harus dipuaskan perusahaan bagi pelanggannya. Perusahaan harus dapat memuaskan tingkat minimal dari kebutuhan pelanggan tersebut, sedangkan dengan customer wants terkait dengan harapan atas keinginan untuk dipenuhi, seperti mutu produk dan pelayanannya, fitur produk tersebut dan model atau desain produk itu.

\section{Produk Spider Fitting}

Spider fitting adalah aksesoris yang berfungsi untuk memasang kaca frameless (juga dapat disebut dengan istilah curtain wall). cara kerja alat ini yaitu menjepit bidang kaca satu dengan lainnya atau berfungsi sebagai media konstruksi sambungan desain kaca, dengan menggunakan aksesoris ini, maka seorang arsitek/perancang dapat bereksplorasi membuat desain bangunan bukaan lebar dari kaca tanpa ada kekhawatiran terlihat frameframe (rangka) pembaginya, spider fitting ada yang memiliki 1 kaki, 2 kaki, 3kaki bahkan 4 kaki.

\section{Pengembangan Produk}

Pengembangan konsep adalah urutan langkah-langkah atau kegiatan-kegiatan di mana suatu perusahaan berusaha untuk menyusun, merancang dan mengkomersialkan suatu produk, sedangkan pengembangan produk itu sendiri merupakan tahapan pertama dalam proses perancangan akhir, yang mencakup kegiatan-kegiatan sebagai berikut: (1) Identifikasi Kebutuhan Pelanggan, (2) Penetapan Strategi Target, (3) Penyusunan Konsep, (4) Pemilihan Konsep, (5) Pengujian Konsep, (6) Penentuan Spesifikasi akhir, (7) Analisis Ekonomi, (8) Perencanaan Proyek

\section{Konsep QFD}

QFD (pengembangan fungsi kualitas) adalah suatu metode untuk perencanaan dan pengembangan produk yang terstruktur yang memungkinkan team pengembangan untuk menentukan keinginan dan kebutuhan pelanggan dengan jelas, dan kemudian mengevaluasi produk atau melayani dengan kemampuan yang secara sistematik dalam pemenuhan keinginan pelanggan tersebut [1].

\section{Manfaat QFD}

Beberapa manfaat yang dapat diperoleh dari QFD bagi perusahaan yang berusaha meningkatkan daya saingnya melalui perbaikan kualitas dan produktivitas secara berkesinambungan: (a) Meningkatkan kualitas, (b) Meningkatkan kepuasan konsumen, (c) Meningkatkan performansi perusahaan, (d) Mengurangi biaya dalam perancangan dan produksi, (e) Meningkatkan keandalan produk, (f) Mengurangi waktu perencanaan dan pengambilan keputusan, (g) Meningkatkan komunikasi, (h) Meningkatkan kesempatan pemasaran, (i) Meningkatkan pengambilan keputusan, (j) Kesempatan untuk meningkatkan keuntungan [2].

\section{Implementasi QFD}

Implementasi dari QFD terdiri dari 3 tahap, dimana seluruh kegiatan yang dilakukan pada masing-masing tahapan dapat diterapkan seperti layaknya suatu proyek, dengan terlebih dahulu dilakukan tahap perencanaan dan persiapan. Ketiga tahapan 
tersebut adalah: tahap pengumpulan suara konsumen (Voice of Customer/VOC) Prosedur umum dalam pengumpulan suara konsumen adalah [1]:

Menentukan atribut-atribut yang dipentingkan konsumen (berupa data kualitatif) dan data ini biasanya diperoleh dari wawancara dan observasi terhadap konsumen.

Mengukur tingkat kepentingan dari atribut-atribut. Tiap atribut mempunyai beberapa data numerik yang berkaitan dengan kepentingan relatif atribut bagi pelanggan dan tingkat performasi kepuasan pelanggan dari produk yang mirip berdasarkan atribut tersebut.

\section{Tahap penyusunan rumah kualitas (House of Quality/HOQ)}

Matriks ini adalah upaya untuk mengkonversi voice of costumer secara langsung terhadap persyaratan teknis atau spesifikasi teknis dari produk atau jasa yang dihasilkan perusahaan akan berusaha mencapai persyaratan teknis yang sesuai dengan target yang telah ditetapkan. Berikut ini adalah struktur matrik pada HOQ:

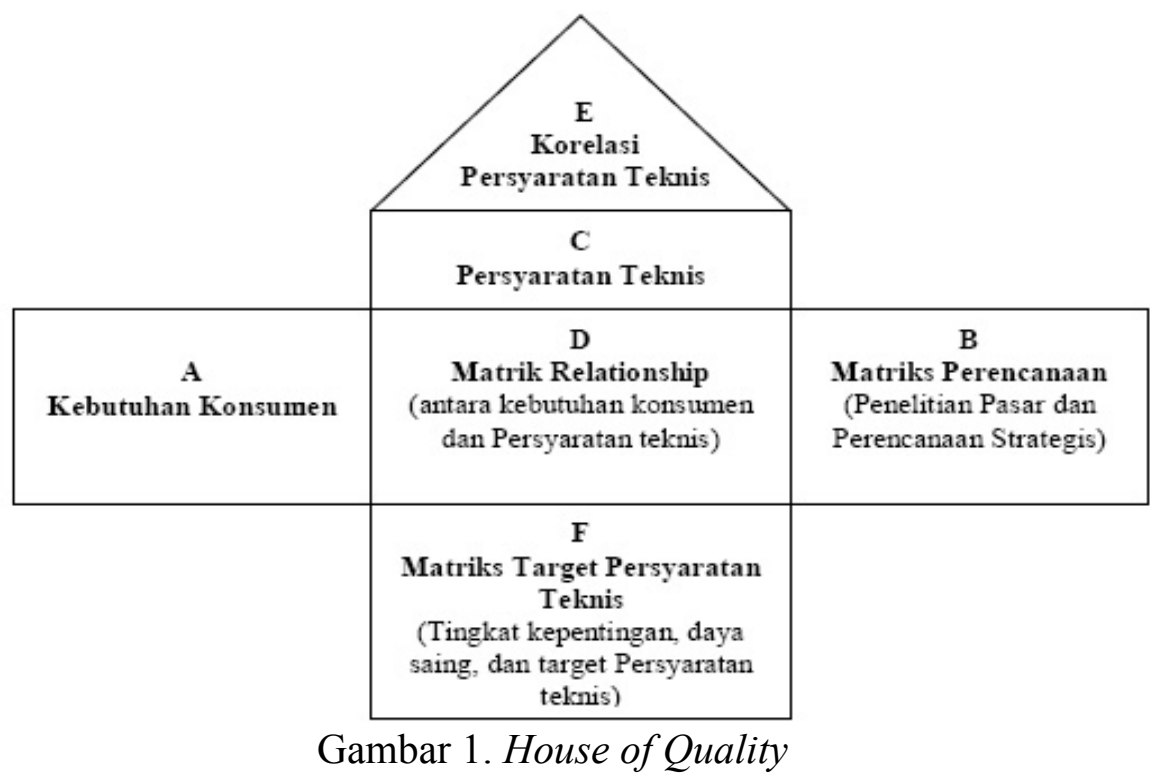

Bagian A. Matriks kebutuhan pelanggan/customer requirements

Bagian B. Matriks perencanaan/planning matrix

Bagian- bagian dari Matriks Perencanaan adalah sebagai berikut:

Tingkat kepentingan pelanggan (Important to Customer)

Kolom tingkat kepentingan pelanggan merupakan tempat dimana hasil pengambilan data mengenai seberapa penting yang suatu atribut kebutuhan.

Tingkat kepuasan pelanggan (Customer Satisfaction Performance)

Tingkat kepuasan pelanggan merupakan persepsi pelanggan mengenai seberapa baik suatu produk atau layanan yang ada saat ini dapat memenuhi kebutuhan pelanggan.

Tingkat kepuasan pelanggan pesaing

Tingkat kepuasan pelanggan pesaing merupakan persepsi pelanggan mengenai seberapa baik suatu produk atau layanan kompetitor dapat memenuhi kebutuhan pelanggan.

\section{Goal}

Goal merupakan target kepuasan pelanggan yang ingin dicapai oleh perusahaan berdasarkan kondisi tingkat kepuasan sebenarnya. 


\section{Improvement Ratio}

Kombinasi dari Customer Satisfaction Performance dan Goal menghasilkan sebuah niali yang disebut Improvement ratio. Improvement ratio merupakan perkalian faktor Goal dan tingkat kepuasan pelanggan (Customer Satisfaction Performance).

$\frac{\text { Goal }}{\text { Customer Satisfaction }}=$ Improvement

\section{Sales Point}

Sales point adalah daya jual yang dimiliki oleh sebuah produk berdasarkan seberapa baik kebutuhan pelanggan terpenuhi. Sales point mempunyai nilai dari salah satu diantara tiga nilai berikut: $1.0,1.2$, dan 1.5. Arti dari ketiga nilai tersebut adalah sebagai berikut:

Tabel 1. Sales point

\begin{tabular}{cl}
\hline 1 & Atribut tidak memiliki daya jual (daya jual rendah) \\
\hline 1,2 & Atribut memiliki daya jual sedang \\
\hline 1,5 & Atribut memiliki daya jual tinggi \\
\hline
\end{tabular}

\section{Raw weight}

Kolom Raw weight berisi nilai dari data dan keputusan yang diambil dari kolomkolom bagian matriks perencanaan sebelumnya. Nilai raw weight adalah sebagai berikut [3]:

Raw weight $=a \times b \times c$

$\mathrm{a}=$ Importance of customer

$\mathrm{b}=$ importance ratio

$c=$ sales point

\section{Normalized raw weight}

Normalized raw weight merupakan presentase nilai raw weigh dari masing masing atribut kebutuhan:[3]

Bagian C. Matriks karakteristik teknis/Substitute Quality Characteristics (SQC)

Matriks ini memuat karakteristik teknis yang merupakan bagian dimana perusahaan melakukan penerapan metode yang mungkin untuk direalisasikan dalam usaha memenuhi keinginan dan kebutuhan konsumen

Bagian D. Matriks hubungan/relationship

Matriks ini menentukan hubungan antara Voice of customer dengan Matriks karakteristik teknis/Substitute Quality Characteristics (SQC)

Tabel 2. Simbol dan nilai matrik interaksi

\begin{tabular}{lcc}
\hline \multicolumn{1}{c}{ Hubungan } & Simbol & Nilai \\
\hline Tidak ada hubungan & & 0 \\
Lemah & $\triangle$ & 1 \\
Moderat & $\bigcirc$ & 3 \\
Kuat & - & 9 \\
\hline
\end{tabular}

Bagian E. Matriks korelasi karakteristik teknis/technical correlation

Matriks ini menggambarkan peta saling ketergantungan (independancy) dan saling 
berhubungan (interrelationship) antara SQC.

Bagian F. Matriks teknis

Bagian terdiri dari urutan tingkat kepentingan, teknik informasi membandingkan kinerja teknis produk.

\section{Skala Likert}

Format tipe likert dirancang untuk memungkinkan pelanggan menjawab dalam berbagai tingkatan pada setiap butir yang menguraikan jasa/produk.

Adapun di dalam skala likert, tingkat kepentingan dan tingkat kepuasan responden terhadap suatu pertanyaan dalam angket diklafikasikan sebagai berikut [4]:

Sangat penting, dengan angka (4)

Penting, dengan angka (3)

Tidak penting, dengan angka (2)

Sangat tidak penting, dengan angka (1)

\section{Penentuan Sampel}

Penentuan jumlah sampel dalam rumus ini menggunakan rumus cachran, yaitu:

$\mathrm{n}=\frac{N \cdot P \cdot Q}{(N-1) D+P \cdot Q}$

$\mathrm{n}=\mathrm{Jumlah}$ minimal sampel

$\mathrm{N}=$ Jumlah rata-rata konsumen

$\mathrm{P}=$ Proporsi responden memilih pertayaan tertentu

$\mathrm{Q}=(1-\mathrm{p})$ Proporsi respoden yang tidak memilih pertayaan tertentu

$\mathrm{D}=$ Tingkat Ketelitian $\left(\mathrm{B}^{2} / \mathrm{Z}_{\mathrm{a} / 2}\right)$

$\mathrm{B}=$ Tingkat kesalahan

\section{Uji Validitas}

Azwar menyatakan bahwa validitas berasal dari kata validity yang mempunyai arti sejauh mana ketepatan dan kecermatan suatu instrumen pengukur (tes) dalam melakukan fungsi ukurnya [5].

$r_{x y}=\frac{N\left(\sum X Y\right)-\left(\sum X \sum Y\right)}{\sqrt{\left.\left(N \sum X^{2}-\left(\sum X^{2}\right)\right) \times\left(\sum Y^{2}\right)\right)}}$

Keterangan :

rxy $\quad=$ koefisien korelasi product moment

$\mathrm{X} \quad=$ nilai dari item (pertanyaan)

$\mathrm{Y} \quad=$ nilai dari total item

$\mathrm{N} \quad$ = banyaknya responden atau sampel penelitian

\section{Uji Reabilitas}

Sudjana (2004) menyatakan bahwa reliabilitas alat penilaian adalah ketepatan alat tersebut dalam menilai apa yang dinilainya. Artinya, kapanpun alat penilaian tersebut digunakan akan memberikan hasil yang relatif sama [6].

$r_{11}=\left(\frac{n}{n-1}\right)\left(1-\frac{\sum \sigma_{t}^{2}}{\sigma_{t}^{2}}\right)$

Keterangan :

$\mathrm{r}_{11}=$ reliabilitas yang dicari 
$\sum \sigma_{\mathrm{t}}^{2}=$ jumlah varians skor tiap-tiap item

$\sigma_{\mathrm{t}}^{2} \quad=$ varians total

\section{METODE PENELITIAN}

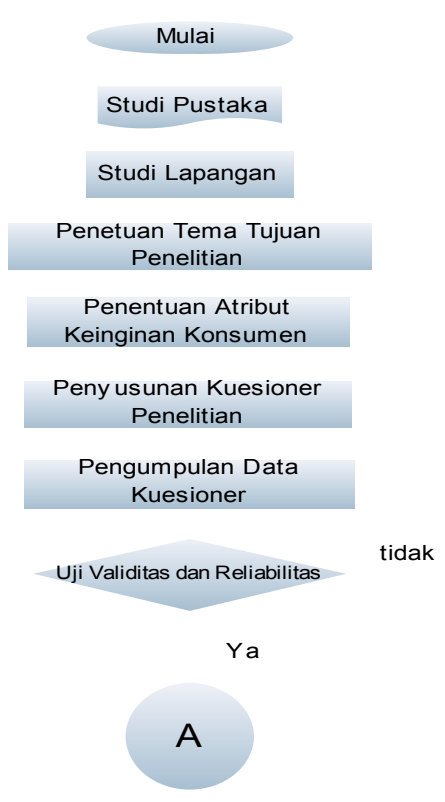

A

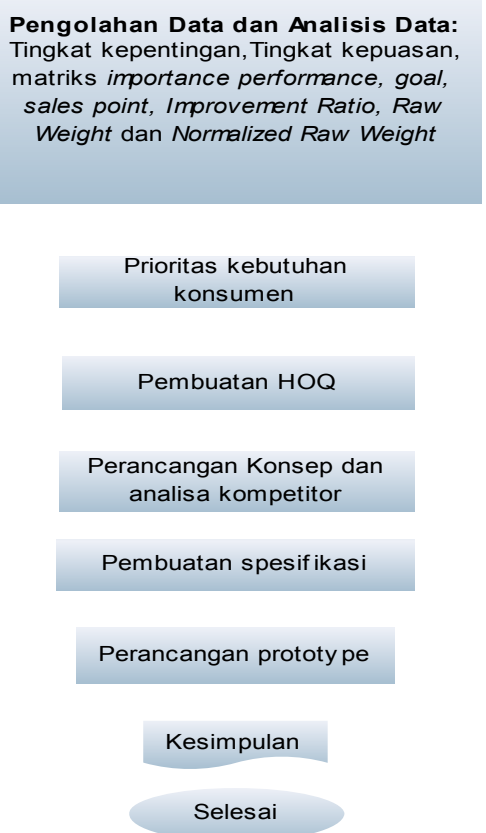

Pengolahan Data dan Analisis Data: ( Weight dan Normalized Raw Weight

oritas kebutuhan konsumen

Pembuatan $\mathrm{HOQ}$

ancangan Konsep dan

Gambar 2. Metodologi Penelitian

\section{Atribut Kebutuhan Konsumen (Voice of Customer)}

HASIL DAN PEMBAHASAN

Atribut kebutuhan konsumen terdiri dari: tahan terhadap korosi, kekuatan kontruksi, Finishing permukaan, kemudahan dalam pemasangan, estetika, warna dan Kemudahan pengaturan sudut kaca.

\section{Pengukuran Tingkat Kepentingan}

Perhitungan ini dimaksudkan untuk menentukan tingkat kepentingan keinginan konsumen pada tiap-tiap atribut yang ditayakan pada kuesioner.

Tabel 3. Pengukuran Tingkat Kepentingan

\begin{tabular}{llcc}
\hline No & \multicolumn{1}{c}{ Atribut } & $\begin{array}{c}\text { Skor } \\
\text { Total }\end{array}$ & $\begin{array}{c}\text { Tingkat } \\
\text { Kepentingan }\end{array}$ \\
\hline 1 & Tahan terhadap korosi & 68 & 3,4 \\
2 & Kekuatan konstruksi & 70 & 3,5 \\
3 & Finishing permukaan & 65 & 3,25 \\
4 & Kemudahan dalam pemasangan & 67 & 3,35 \\
5 & Estetika & 66 & 3,3 \\
6 & Warna & 55 & 2,75 \\
7 & Kemudahan pengaturan sudut kaca & 69 & 3,45 \\
\hline
\end{tabular}




\section{Pengukuran Tingkat Kepuasan}

Pengukuran tingkat kepuasan digunakan untuk melihat seberapa tingkat kepuasan responden pada setiap atribut yang ditanyakan melalui kuesioner.

Tabel 4. Pengukuran Tingkat Kepuasan

\begin{tabular}{clcc}
\hline No & \multicolumn{1}{c}{ Atribut } & $\begin{array}{c}\text { Skor } \\
\text { Total }\end{array}$ & $\begin{array}{c}\text { Tingkat } \\
\text { Kepuasan }\end{array}$ \\
\hline 1 & Tahan terhadap korosi & 66 & 3,3 \\
2 & Kekuatan konstruksi & 61 & 3,05 \\
3 & Finishing permukaan & 59 & 2,95 \\
4 & Kemudahan dalam pemasangan & 60 & 3 \\
5 & Estetika & 67 & 3,35 \\
6 & Warna & 67 & 3,35 \\
7 & Kemudahan pengaturan sudut kaca & 58 & 2,9 \\
\hline
\end{tabular}

\section{Matriks Importance Performance Analysis}

Berdasarkan perhitungan tingkat kepentingan dan tingkat kepuasan, maka dilakukan pembuatan berupa matriks Importance Performance.

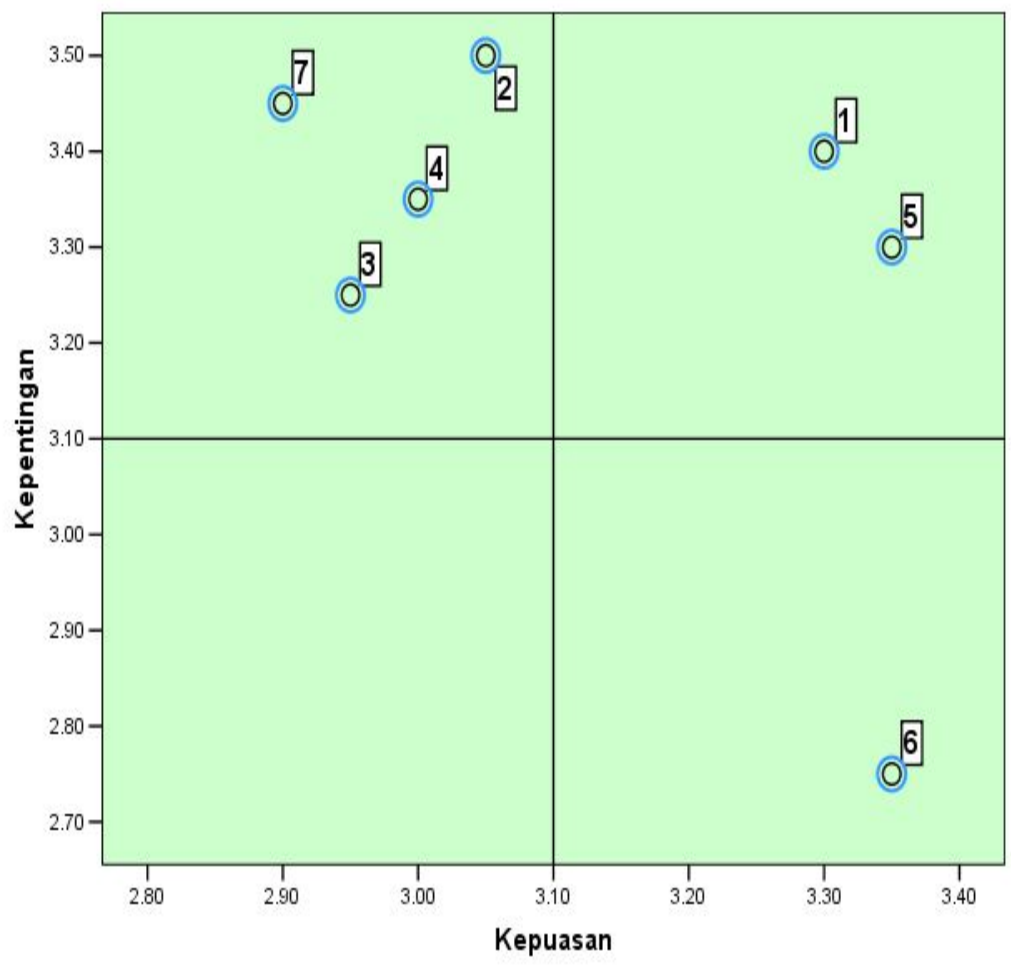

Gambar 3. Matriks Importance Performance Analysis

Kuadran 1 merupakan prioritas utama yang memuat atribut produk yang dianggap penting tetapi pada kenyataannya atribut tersebut belum sesuai dengan harapan yang diinginkan. Termasuk dalam kuadran ini adalah atribut nomor 2 (Kekuatan konstruksi), 3 (Finishing permukaan), 4 (Kemudahan dalam pemasangan) dan 7 (Kemudahan pengaturan sudut kaca). Atribut yang terdapat dalam kuadran ini harus lebih di tingkatkan lagi, agar dapat memuaskan para konsumen. Atribut tersebut merupakan prioritas utama suatu perusahaan untuk meningkatkan terlebih dahulu.

Kuadran 2 merupakan kuadran yang memuat atribut produk yang dianggap penting namun atribut itu telah sesuai dengan harapan konsumen. Termasuk dalam kuadran ini 
adalah atribut nomor 1(Tahan terhadap korosi) dan atribut nomor 5 (Estetika). Atribut tersebut perlu dipertahankan untuk waktu selanjutnya karena konsumen sudah merasa puas terhadap atribut tersebut.

Kuadran 3 merupakan kuadran yang memuat atribut produk yang dianggap kurang penting namun atribut tersebut belum memenuhi harapan konsumen. Atribut tersebut merupakan prioritas rendah untuk ditingkatkan oleh perusahaan, hal ini dikarenakan peningkatan terhadap atribut tersebut memberikan suatu manfaat yang rendah daripada peningkatan pada prioritas utama.

Kuadran 4 merupakan kuadran yang memuat atribut produk yang dianggap berlebihan yang berisi suatu atribut produk yang dianggap kurang penting akan tetapi telah sesuai dengan harapan konsumen, termasuk didalam kuadran ini adalah atribut nomor 6 (Warna). Atribut tersebut termasuk dalam kategori berlebihan yang berarti peningkatan terhadap atribut tersebut hanya akan menyebabkan pemborosan tanpa adanya manfaat besar yang dirasakan oleh konsumen.

\section{Technical Responses}

Technical Responses terdiri dari (1) Menggunakan stainless steel jenis 316, (2) Menggunakan plat stainless steel yang memiliki ketebalan 3 mm-6 mm, (3) Melakukan finishing mirror, (4) Membuat kepala baut segi enam sehingga memudahkan dan menunjang kekuatan penguncian kaca, (5) Melakukan desain model spider fitting, (6) Membuat produk spider fitting yang fleksibel dalam pengaturan sudut kaca,

(7) Menggunakan warna dasar stainless steel

\section{Hasil Perhitungan}

Hasil perhitungan tingkat kepentingan, tingkat kepuasan, goal, sales point, improvment ratio, raw weight, dan normalized raw weigh dapat di lihat pada Tabel 5.

Tabel 5. Hasil Perhitungan

\begin{tabular}{ccccccccc}
\hline No & Atribut & $\begin{array}{c}\text { Tingkat } \\
\text { Kepentingan }\end{array}$ & $\begin{array}{c}\text { Tingkat } \\
\text { Kepuasan }\end{array}$ & Goal & $\begin{array}{c}\text { Sales } \\
\text { Point }\end{array}$ & $\begin{array}{c}\text { Improvment } \\
\text { Ratio }\end{array}$ & $\begin{array}{c}\text { Raw } \\
\text { Weight }\end{array}$ & $\begin{array}{c}\text { Normalized } \\
\text { Raw Weight }\end{array}$ \\
\hline 1 & $\begin{array}{c}\text { Tahan terhadap } \\
\text { korosi }\end{array}$ & 3,4 & 3,3 & 3 & 1,2 & 0,91 & 3,71 & 0,10 \\
\hline 2 & Kekuatan konstruksi & 3,5 & 3,05 & 4 & 1,5 & 1,31 & 6,88 & 0,19 \\
\hline 3 & Finishing permukaan & 3,25 & 2,95 & 4 & 1,5 & 1,36 & 6,63 & 0,18 \\
\hline 4 & $\begin{array}{c}\text { Kemudahan dalam } \\
\text { pemasangan }\end{array}$ & 3,35 & 3 & 4 & 1,2 & 1,33 & 5,35 & 0,15 \\
\hline 5 & Estetika & 3,3 & 3,35 & 3 & 1,2 & 0,9 & 3,56 & 0,10 \\
\hline 6 & Warna & 2,75 & 3,35 & 3 & 1,2 & 0,9 & 2,97 & 0,08 \\
\hline 7 & $\begin{array}{c}\text { Kemudahan } \\
\text { pengaturan sudut } \\
\text { kaca }\end{array}$ & 3,45 & 2,9 & 4 & 1,5 & 1,38 & 7,14 & 0,20 \\
\hline
\end{tabular}

\section{Spesifikasi Produk}

Dari konsep yang telah di buat, kemudian dilakukan pemilihan serta pembuatan spesifikasi. Hasil rancangan produk pada konsep ke 3 dapat dilihat pada Tabel 6, Gambar 4 dan Gambar 5. 
Tabel 6. Spesifikasi

\begin{tabular}{clc}
\hline No & \multicolumn{1}{c}{ Spesifikasi } & Keterangan \\
\hline 1 & Baut penjepit kaca & $30 \mathrm{~mm} \times 5 \mathrm{~mm}$ \\
2 & Lengan penyangga & $80 \mathrm{~mm} \times 40 \mathrm{~mm}$ \\
3 & baut segi enam & $5 \mathrm{~mm}$ \\
4 & Batang penyambung & $40 \mathrm{~mm} \times 40 \mathrm{~mm}$ \\
5 & Engsel penjepit kaca & $40 \mathrm{~mm} \times 30 \mathrm{~mm}$ \\
6 & Dop penutup baut penjepit & $31 \mathrm{~mm} \times 6 \mathrm{~mm}$ \\
7 & Finishing & Mirror \\
8 & Menggunakan jenis stainless steel & 316 \\
9 & Warna stainless steel & Silver \\
\hline
\end{tabular}

Fungsi dari tabel spesifikasi di atas adalah sebagai berikut: baut penjepit kaca berguna untuk mengunci kaca dengan bagian engsel penjepit kaca yang di rancang untuk dapat di atur. Lengan penyangga berguna sebagai penghubung bagian engsel penjepit kaca. Kepala baut segi enam digunakan untuk mengunci bagian engsel penjepit kaca setelah dilakukan pengaturan sudut kaca, dan sebagai kepala baut penjepit kaca untuk memudahkan penguncian kaca. Batang penyambung merupakan penghubung antara dua lengan spider fitting dan bagian engsel penjepit kaca. Engsel penjepit kaca meruapakan bagian yang dapat diatur sebagai bagian untuk mengatur sudut kaca. Dop penutup baut penjepit merupakan suatu bagian untuk menutup baut sehingga kepala baut segi enam tidak terlihat.

Gambar 4.Tampak Depan Spesifikasi Konsep 3

Gambar 5. Tampak Atas Spesifikasi Konsep 3

\section{Perbandingan Spider Fitting Sebelum dan Setelah}

Berikut adalah perbandingan spider fitting pada PT.karya Logam sebelum dilakukan pengembangan produk dan spider fitting setelah dilakukan pengembangan produk. Produk PT.Karya Logam dan produk setelah dikembangkan dapat dilihat pada Gambar 6 dan 7. 


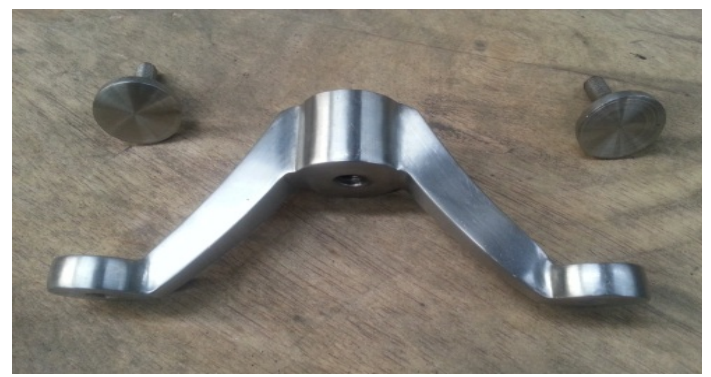

Gambar 6. Spider fitting PT.Karya Logam

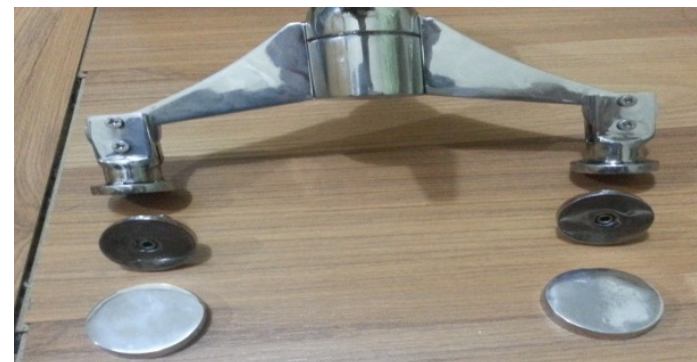

Gambar 7. Spider fitting setelah dikembangkan

\section{KESIMPULAN}

Dari hasil analisa dan pengolahan data yang dilakukan pada bab sebelumnya, maka dapat dibuat kesimpulan sebagai berikut: Atribut kebutuhan konsumen yang akan dikembangkan terdiri dari tujuh atribut. Dari tujuh atribut tersebut didapatkan kebutuhan kemudahan pengaturan sudut kaca, kekuatan konstruksi, finishing permukaan dan kemudahan pemasangan yang menjadi atribut prioritas pengembangan. Berikut ini adalah saran technical respon yang dapat diberikan kepada PT. Karya Logam dengan ranking empat teratas yang didapat dari matriks HOQ yang menjadi pencapaian kebutuhan konsumen adalah membuat produk spider fitting yang fleksibel dalam pengaturan sudut kaca, finishing mirror, membuat kepala baut segi enam sehingga memudahkan dalam penguncian kaca dan menggunakan plat stainless steel yang memiliki ketebalan 3mm-6mm sehingga menunjang kekuatan struktur spider fitting. Produk usulan konsep tiga memiliki keunggulan dalam hal kemampuan untuk pengaturan sudut kaca, kemudahan pemasangan baut penjepit kaca dari produk sebelumnya, finishing mirror yang membuat spider fitting terlihat lebih berkilau dan kekuatan struktur konstruksi lebih baik dari ketebalan plat yang digunakan.

\section{DAFTAR PUSAKA}

[1] Cohen, Lou. (1995). Quality Function Deployment: How to Make QFD Work for You. Massachussetts. Singapore: Addison Wesley Publishing Company.

[2] Besterfield, Dale H. (1994). Quality Control. Fourth Edition. Prentice Hall.

[3] Tampubolon, D.P. (2001). Perguruan Tinggi Bermutu: Manajemen Strategis. Jakarta: PT. Gramedia Pustaka Utama.

[4] Abdul Rahman, dan Heri Supomo. (2012). Analisa Kepuasan Pelanggan Pad Pekerjaan Kapal dengan Metode Quality Function Deployment (QFD). Surabaya: ITS.

[5] Matondang, Zulklifi. (2009). Validitas dan Reabilitas Suatu Instrumen Penelitian. Medan: Universitas Negeri Medan. Jurnal Tabularasa Pps Unimed Vol.6 No.1. 87-97

[6] Sudjana. (2002). Metode Statistika. Bandung: Tarsito. 